\title{
Development of Higher Education Service Model Through Total Quality Service of Three Pillars of Tertiary Education in Universitas Negeri Gorontalo
}

\author{
Ismet Sulila \\ Study Program of Public Administration \\ Universitas Negeri Gorontalo \\ City of Gorontalo, Gorontalo Province
}

\begin{abstract}
The study of the Development of Higher Education service model through total quality service of Three Pillars of Tertiary Education (research, teaching and community service) in Universitas Negeri Gorontalo (UNG) aimed at comprehensively studying the effectiveness of Three Pillars of Tertiary Education implementation and finding out the factors, which support and inhibit the delivery of Three Pillars of Tertiary Education. This study also aimed at developing Three Pillars of Tertiary Education model through total quality service in Universitas Negeri Gorontalo. This was a qualitative descriptive study, where the data had gone through data collection, data reduction, data display, and conclusion drawing stages. In addition, the focus group discussion was also conducted in each stage of the study involving related stakeholders, internal and external stakeholders. This study revealed: 1) Overall, the academic services implemented in Universitas Negeri Gorontalo have not met the standard of quality assurance. 2) There were many determinant factors in implementation of quality assurance based services that suit the characteristics of each services provided in three higher education services, such as: human resources, facilities and infrastructure, and regulation certainty to standardize each types of academic services, 3) development of academic service model through total quality service could be implemented through implementation of public service dimensions, which consists of tangible, assurance, responsiveness, reliable and empathy. Implementation of this research outcome was expected to positively contribute to the innovation of Three Pillars of Tertiary Education for the construction of one of higher education pillars, the quality assurance, in Universitas Negeri Gorontalo.
\end{abstract} Service

Keywords-Three Pillars of Tertiary Education, Total Quality

\section{INTRODUCTION}

The paradigm of public service delivery has brought wider consequences in development. During the 1990s, there was a very famous normative paradigm called, "reinventing government" (Osborne \& Gabler, 2005) [1], where the concept of public management was developed. The public management, as stated by Keban (2004) [2], has gone through paradigm shifting and development. Consequently, this has made the models and approaches used in public management to change and to develop.
In education service delivery the consequence of those changes has demanded the higher education to continually try their best in education service delivery. This is reflected in the delivery of more autonomous and more decentralized education delivery compared to the old paradigm where everything was centralized and under the direct control of central government.

Popular definition of decentralization concept is as delegation of authority from manager to the implementer. Whereas, autonomy means independency. Independency in this context is independency to select and deliver education services, independency that goes hand in hand with ability. The changes in the paradigm of education delivery has made higher education institute as the frontline in implementation of literacy for the people, especially in the delivery of three higher education services for the community.

Within academic concept, autonomy in implementation of higher education is a crucial and interesting issue to be scientifically studied. The development of autonomous higher education concept has to be viewed as an opportunity for that higher education to be an institution with competitive advantages, hence, would ease the achievement of its vision and missions.

As the biggest higher education institution in Gorontalo province, Universitas Negeri Gorontalo plays critical role in the implementation of three higher education services that consists of education, research, and community services. These three main functions are implemented through four pillars of Universitas Negeri Gorontalo development, which consists of 1) Quality Assurance, 2) Information and Technology, 3) Development of Soft Skill, and 4) Environment.

These four development pillars of higher education as mentioned before are the basis in development of programs, policy and implementation of the various tasks of units within the Universitas Negeri Gorontalo. These four pillars are the new basis that have been implemented for the last four years. The success of the implementation of these four pillars would ensure the success of the institution to realize its vision and missions, both in short term and long term. Within this framework, a further study is needed to be focused on one of 
the pillars, the Quality Assurance that is the development of higher education service model through total quality service of Three Pillars of Tertiary Education in Universitas Negeri Gorontalo.

Based on the background described above, this study will be focused on three aspects, first: effectiveness of three higher academic services, second: determinant factors, either support or inhibit the implementation of three higher academic services, third: development of Three Pillars of Tertiary Education through total quality service in Universitas Negeri Gorontalo

\section{METHOD}

\section{A. Types of Research}

Based on the problems proposed above, this is a descriptive qualitative study, which describes, records, and interprets the total quality service approach through the implementation of public service dimensions in Universitas Negeri Gorontalo

\section{B. Source of Data and Data Collection Method}

The data in this study are obtained from students, lecturers and community as the recipients of the Three Pillars of Tertiary Education, including the implementers in each strategic work units within Universitas Negeri Gorontalo. The data are collected through interview, documentation, and observation. these three techniques are used to be able to focus on investigating the focus of study.

\section{Data Analysis}

The procedure of data analysis in this study are data collection, data reduction, data presentation and conclusion drawing as described by Sanafiah Faisal (2005).

\section{RESULTS AND DISCUSSION}

Within the context of implementation of higher education, autonomy is an expectation of each higher education to make their institution a world class university. In implementing its functions, higher education institute is focused on Three Pillars of Tertiary Education, that is, teaching and learning, research, and community services. These three focuses are integrated parts of the higher education. Good implementation of education will impact on producing a better research outcome, and in turn, good research outcomes will serve the community better. The findings on these three focuses are presented as follow:

\section{A. Academic Services Effectivenes in Universitas Negeri Gorontalo}

The efforts to implement the tree focus of this researchteaching and learning, research, and community development - are closely related to the academia's functions and tasks, which are manifested through the process. Within the concepts of service delivery, there are servants, those who are served, and also types of services provided. In this study on Three
Pillars of Tertiary Education, the concept of service above is described as follow:

\section{- Academic services in teaching and learning}

There are several academic services in teaching and learning sector in Universitas Negeri Gorontalo such as, 1) Online Study Plan (KRS)/Online Study Result (KHS). KRS is service is provided since the beginning of a term, where students input subjects that they enrolled to in that semester. The academic advisors then verify and approve the plan. Whereas, the KHS online is a service provided for students after the lecturers input their grades for all subject in that semester at the end of each term. This study reveals that there is not any flow chart provided that can assist students in accessing this service. 2) Teaching and Learning Process/ Mid Term Examination/Final Examination. This service is provided after the KRS was approved by the academic advisor. The lecture is given face to face for 16 meetings, at the eight meeting, the midterm test is carried out and at the $16^{\text {th }}$ meeting the final exam is carried out. This study reveals that there is not any flow chart provided that can be seen by the students on how this service is carried out. 3) Academic Advising. This service is provided by each academic supervisor relation to problems faced by the students in their academic life. However, this study reveals that this function has not been properly carried out, yet. Most students only meet their academic advisor for their KRS approval at the beginning of the semester. This service also does not clearly points out its functions and how this service is provided in each departments. 4) Practicum. This academic service is only provided for certain subjects based on the curriculum. This study shows that the mechanism to propose for a practicum, the implementation, and the reporting has not been showing a clear mechanism on how this service is provided. 5. Community practice/Internship/Study Visit/Field Practice. These services are specially provided by students who are nearing the end of their study. This study reveals that there are no service flow process in each faculties that can help the students and lecturers in implementing those activities. 6) final project/skripsi proposal, research and skripsi examination. These services are given to the students at their final year at university. It is started by proposal registration, assigning the academic supervisors and examiners, scheduling the proposal examination, revision of the skripsi proposal based on the input during the exam. Meanwhile, the skripsi examination proposal service is comprised of registration, examination of the drafts of research result, scheduling the exam, and implementation of the examination. Whereas, the final skripsi examination service consists of registration, examination of the exam documents, scheduling, examination and judicium. Each faculty have different standard in implementation of this skripsi examination. This difference should have been standardized by an academic guideline at university level. This study reveals that there is no easy to understand flow chart of this services that are available to students and lecturers to access these services. 7). Graduation. This service is provided for students who have completed all their academic responsibilities in their respective departments. This service is started with verification of graduation documents in department level and followed by online registration for 
graduation. Further service on graduation is conducted by the Administration Academic Bureau. This study reveals that there is no standardization on quality service for students to access this service.

\section{- Academic Services in Research Field}

In research service, the faculty, through its staffs provides services for the lecturers. The study reveals that this service has not yet properly implemented. There is no standardized process on how to submit and establish research implementers in each faculty and departments. Currently, the process consists of announcement of proposal submission in each department. The departments then decide which proposals that will be funded by the faculty. In this stage, there are no proposal seminars and research findings seminar held in department and faculty level.

\section{- Academic service in Community Service sector}

Within the community service context, this service is provided by the staffs in department and faculty level for all lecturers in departments or faculty level. This research shows that the process of this service delivery has not been as expected. This is evident in the inexistence of clear procedure on community service program proposed either in department or in faculty level. Currently, the proposal for community service in each departments are not widely published to make them more competitive, and the department also proposed the team to conduct this community service to the faculty without any selection process.

\section{B. Determinant Factors, both factors that supports and} factors that inhibit the delivery of Three Pillars of Tertiary Education in Universitas Negeri Gorontalo

Factors that support and inhibit the delivery of Three Pillars of Tertiary Education can be described as follow:

\section{- Academic Services in teaching and learning}

The determinant factors in this aspects are as follow: 1) in KRS/KHS. The study shows that several factors determine the success of this service delivery, namely: availability of service facilities and infrastructure, operator competencies in each department, internet network. 2) Lecture service/Mid Term Examination/Final Examination service. The determinant factors for these services are availability of lecture facilities and infrastructure, online lecture schedule, competencies of lecturers, and availability of internet network. 3) academic advisory service. The determinant factors are lecture to students ration, academic advisory schedule in each semester, and lecture competencies to conduct academic advisory. 4) Subject Practicum. The determinant factors are availability of practicum facilities and infrastructure, reconstruction of practicum subject, content material for practicum, lecturer's competencies and practicum procedure. 5) Community Service/Internship/Study Visit/Teaching Practice. The determinant factors for these services are: implementers, financial resources, activity procedure, and lecturer's competencies in the field. 6) Academic services on proposal seminar, research result, and skripsi examination. The determinant factors are service procedure, supervisors to students being supervised ration, supervisors' competencies and examiners' competencies, and sufficient examination room. 7) Graduation Service. The determinant factors for graduation service are competencies of the staff to conduct strict verification on the graduation requirements, internet network for online graduation registration, and availability of facilities and infrastructure for graduation.

\section{- Academic Research Services}

Within the context of academic research services, the service provided by the faculty through the staffs for the lecturers. This study reveals that this service has not been properly implemented. This is evident in the inexistence of procedure that should be made in accepting and establishing the winners for research grants. Therefore, this study proposes the stages of services that have to be given for lecturers who conduct research. The stage of services are: 1) announcement for lecturers in all work units, 2) proposal acceptance based on the time line, 3) scheduling the seminar proposal in faculty level, 4) implementation of seminar in faculty level, 5) announcement of the winners in each faculty, 6) implementation of research, 7) implementation of monitoring and evaluation, 8) implementation of research result seminar, 9) submission of final research report.

\section{- Academic Service in Community Service}

In community service context, this service is provided by the staffs in research unit for lecturers. The research reveals that this service process is not yet as expected. The stages are important in this service to ease lecturers in implementing their community service tasks. However, the inexistence of clears stages in this service has impact on two things, first, lack of lecturers' enthusiasm to conduct community service, 2) lack of community service implemented for the society.

In addition, within the context of community service, sustainability is needed for each community service to carried out in the next academic year. This is intended to implement many research results in community, hence, it will bring benefits for the community that were previously made as the object of research.

\section{Development of Three Higher Academic Services through Total Quality Service in Universitas Negeri Gorontalo}

Development of service model in this study is the implementation of public service dimensions to ensure the quality of Three Pillars of Tertiary Education.

\section{- Academic Service in Teaching and Learning}

Several dimensions of services can be described as follow: 1) KRS/KHS online. The service dimension that should be implemented in this service is the Tangible dimension, which consists of fulfilling the facility and infrastructure for online KRS, internet network, provision of computer in campus area. 2) Teaching and learning process/Mid Exam/Final Exam. In this service, the tangible dimension of public service need to be implemented by providing the sufficient classroom facilities, such as LCD projector, chairs, and air conditioner. In addition, the assurance dimension is also needed. This dimension includes lecture qualification, lecturing frequency, 
and learning equipment. 3) Academic advisory. In this service, responsiveness and empathy dimensions are needed. Responsiveness dimension emphasizes on the speed and appropriateness of lecturer as academic advisor in responding to the problems faced by the students in their academic life. Whereas, the empathy dimension insists upon lecturer as academic advisor to comprehensively understand the problems faced by students that impacted on their academic life. 4) Lecture practicum. This services is provided for students to practice the theory that they have learnt during their study in the class. Hence, the tangible and assurance dimensions are needed. Tangible dimension insists upon the provision of practicum facilities, while, assurance dimension insists upon the need to ensure that the practicum result can become a learning experience for students. 5) Community Practice/Internship/Study Visit/Practice Teaching. In these type of services, reliable and assurance dimensions are needed. Reliable dimension refers to the need of well preparedness in the implementers to provide these services before the students are sent to the field up to when they return to the university. On the other hand, assurance dimension refers to the service assurance from the implementers toward the programs and their benefits for the students, community, campus, and for the government. 6) skripsi proposal, result seminar, and skripsi examination. In these services, reliable and assurance dimensions are needed. The reliable dimension insists on the service procedures where student should go through since their research proposal examination, to their result examination, up until their final skripsi/research examination. On the other hand, the assurance dimension emphasizes the assurance needed to ensure that service procedure is implemented properly. 7) Graduation. In this service, reliable dimension is needed. This dimension insists on the aspects of services received by the students since they register for graduation, to the graduation ceremony, and up to handover of their diploma certificates.

\section{- Research Academic Service}

In the above findings, it has been explained that there is currently no procedure on research academic service, and there are factors that determine the success of this service. Therefore, this study reveals that there is a service to collect research proposal from all faculties, in which this service consists of: 1) announcement of research opportunities for lecturers in all faculties, 2) proposal submission invitation based on the determined time line, 3) scheduling seminar proposal in department level, 4) implementation of proposal seminar in each department, 5) announcement of winners in each department, 6) implementation of research, 7) implementation of monitoring and evaluation, 8) implementation of research result seminar, 9) submission of final research report.

In an effort to implement a quality assurance-based service, the mechanism of academic service in research aspect as mentioned above needs to have five service dimensions, namely, tangible dimension, which consists of preparation of implementer resources, online computer network. Second dimension is reliability dimension which consists on the clarity of procedure mechanism to propose for a research. Third, responsiveness dimension consists of implementer's responsibility in proposing for the research in certain scheme of research. Fourth, assurance dimension to ensure the process of proposing for a research can be conducted accordingly. The last dimension is the empathy dimension where it comprises of the staffs ability (academic staffs) to provide appropriate service for users.

The services provision by implementation of public service dimensions as proposed above ideally will become a fixed procedure in research programs. The institutionalization of this service procedure can be done by the head of faculty as long as it is not against the academic service regulation above it. Through the existence of this clear and measurable procedure to conduct research, it will be a motivation for lecturers and students to implement various researches.

\section{- Academic Community Service}

This study shows that there is a need for a procedure mechanism in proposing for a community service project. Further, within the context of community service, this service will be provided by the staffs in department and faculty level for the lecturers. The importance of the stages in this activity will help lecturers to implement their community practice tasks. However, the inexistence of standardized service stages has caused two things, 1) lack of lecturers' enthusiasm in implementing community service, 2) lack of quality of the community service.

In addition, in the context of community service funded by PNBP (Non-Tax State Revenue Funding) sustainability is needed to carry on the result of the research from each department to be further implemented as community service in the following academic year. This is aimed to implement the research result in the community, hence, research will give more benefit for the community as the object of research.

In implementation of community service program that is carried out as the result of the previous research, students' participation are needed. Therefore, students' participation aspect should become one of the stage in community service implementation. Some benefits of this are: 1) increase the willingness and ability of the students to implement their knowledge in the society, 2) increase the lecturers' role in transferring their knowledge and servicing the community through the role of their students.

The mechanism for this community service delivery consists of: 1) announcement of the community service proposal for the lecturers, 2) announcement of the proposal acceptance based on the decided timeline, 3) schedule the seminar in the department level, 4) implement the seminar in each department, 5) establish the winner in each department, 6) implement the community service,7) implement the monitoring and evaluation, 8) implement the result of the research seminar, 9) submission of the final research report.

As in ensuring quality assurance for research aspect, ensuring the quality assurance for community services also needed five dimensions of services, tangible dimension which consists of preparation of implementer resources, online computer network; reliability dimension which consists of clarity of procedure mechanism in proposing the community service; responsiveness dimension that encompasses the 
implementer 's responsibility in proposing a community service within certain scheme funding; assurance dimension, which consists of assurance on the process of proposing the community service which can be done properly, and empathy dimension that consists of the ability of the implementers (academic staffs) on the service provided for the each user.

As a government institution, in implementation of the Three Pillars of Tertiary Education, Universitas Negeri Gorontalo should have referred to the Decree of Ministry of The State Apparatus Empowerment of the Republic of Indonesia No. 633 of 2003. In which, in this decree, the ministry insists that to improve the quality of public service, the delivery of the service should have met several principles as follow: 1) simplicity, 2) clarity, 3) time certainty, 4) accuracy, 5) safety, 6) responsibility, 7) comprehensiveness of infrastructure and facilities, 8) ease of access, 9) discipline, hospitality, and 10) comfort.

This study reveals that the academic service in teaching and learning, research, and community services have not yet reflect the dimension of public service as an assurance toward the quality of the service. Therefore, total quality service of three higher education academic service in Universitas Negeri Gorontalo can be done through fulfillment of the resource, infrastructure and facilities needed, and the standardization and simplification of services.

In addition, within the process of public service delivery based on the quality assurance, as proposed by Parasuraman (1998) on five dimensions of public service delivery in order to achieve the desired quality, namely 1) tangible, which comprises of physical ability, tools, personnel, and material communication. 2) Reliable dimension, which consists of ability to provide the service as promised accurately and timely, 3) Responsiveness that is the responsibility toward the quality of provided service. 4) Assurance that is knowledge, behavior, and the personnel's ability. 5) Empathy that is personal attitude toward the service user.

\section{CONCLUSION AND RECOMMENDATION}

Following the findings and discussion above, the following conclusions are reached: 1) academic services implemented in Gorontalo State University, overall have not yet met the standard of quality assurance. 2) There are several determinant factors in the implementation of services based on the quality assurance that suits the characteristics of each component of the Three Pillars of Tertiary Education. 3) Reconstruction of academic service model based on quality assurance can be developed and implemented through total quality service on the implementation of public service dimensions in Three Pillars of Tertiary Education.

Quality assurance based public services is one of the pillars in establishing a competitive institution as one of the efforts of Universitas Negeri Gorontalo to become World Class University. Therefore, it is recommended for other units within this university to adopt and to implement the model of academic services based on quality assurance as the output of this research in their respective units.

\section{REFERENCES}

[1] Faisal Sanapiah, Social Research Formats/Format-Format Penelitian Sosial, PT. Raja Grafindo Persada, Jakarta, 2005.

[2] Osborne David \& Gaebler Ted, Reinventing Government (Mewirausahakan Birokrasi), Transl: Abdul Rosyid, PPM, Jakarta, 2005.

[3] Keban, Yeremias t, Six Dimension of Strategic Public Administration: Concept, Theory and Issues/Enam Dimensi Strategis Administrasi Publik: Konsep, Teori dan Issue. Yogyakarta: Gava Media, 2004.

[4] Parasuraman A, Assesment of Expectations as A Comparison Standart in Measure of Quality: Implications for Further Research, Journal Organisasi Market Services, January, 1998, pp.111-124.

[5] Ratminto \& Atik Septi Winarsih, Service Management/Manajemen Pelayanan, Jakarta, Pustaka Pelajar, 2006.

[6] General Guideline for Public Service Delivery; Decree of the Ministry of State Apparatus Empowerment No. 63 of 2003/ Keputusan Menpan No 63/KEP/M.PAN/7/2003 tentang Pedoman Umum Penyelenggaraan Pelayanan Publik. 